\title{
ANALISIS DAYA SAING DAGING AYAM : STUDI KASUS DI KABUPATEN SLEMAN
}

\author{
Mujtahidah Anggriani UM'
}

\section{INTISARI}

Penelitian ini dimaksudkan untuk mengetahui daya saing daging ayam dilihat dari keunggulan kompetitif dan komparatif. Indikator keunggulan kompetitif dan keunggulan komparatif menggunakan nilai Private Cost Ratio (PCR) dan Koefisien Biaya Sumberdaya Domestik (KBSD). Data primer hasil wawancara dengan peternak ayam dan data sekunder adalah data dasar yang digunakan dalam analisis daya saing ini. Penelitian dilakukan di Kabupaten Sleman terhadap 30 responden dengan menggunakan metode deskriptif. Hasil perhitungan menghasilkan PCR dan KBSD sebesar 0,06837 dan 0,12767 . Kedua nilai indikator ini menunjukkan nilai kurang dari satu artinya usaha ternak ayam efisien secara finansial dan ekonomi dalam penggunaan sumberdaya domestik atau dengan kata lain usaha ini berdaya saing.

(Kata kunci : Daya saing, Keunggulan kompetitif, Keunggulan komparatif, Daging ayam).

Buletin Peternakan 28 (3) : 142 - 147, 2004

${ }^{1}$ Fakultas Petemakan Universitas Gadjah Mada, Yogyakarta. 


\title{
COMPETTTIVENESS ANALYSIS OF CHICKEN MEAT : CASE STUDY IN SLEMAN REGENCY
}

\begin{abstract}
This research was intended to know the competitiveness of chicken meat based on competitive and comparative advantages. The indicators of competitive and comparative advantages were the value of Private Cost Ratio (PCR) and the Domestic Resources Cost Ratio (DRCR). The primary data obtained from the result of interview with the chicken farmers and secondary data were used as basic data in this analysis. The ressearch was conducted in Sleman Regency with 30 respondents using descriptive method. The results of the research showed that the values of PCR and DRCR were 0.06837 and 0.12767 respectively. Both indicator values were less than one meaning that chicken farming was financially and economically efficient in using domestic resources, in other words chicken farming had competitiveness.
\end{abstract}

(Key words : Competitiveness, Competitive advantage, Comparative advantage, Chicken meat).

\section{Pendahuluan}

Perkembangan ekonomi Indonesia yang mengarah pada globalisasi ekonomi menuntut sektor peternakan untuk mampu menghasilkan produk-produk unggulan yang mempunyai daya saing baik untuk pasar domestik maupun pasar internasional.

Daya saing adalah kemampuan suatu produsen untuk memproduksi suatu komoditi dengan mutu yang cukup baik dan biaya produksi yang cukup rendah sehingga pada harga-harga yang terjadi di pasar internasional dapat diproduksi dan dipasarkan oleh produsen dengan memperoleh laba yang mencukupi, sehingga dapat mempertahankan kelanjutan kegiatan produksinya (Suprihanti, 1998).

Pendekatan keunggulan kompetitif dan komparatif digunakan untuk menganalisis daya saing nenas kaleng di Indonesia telah dilakukan oleh Suprihatini (1998). Keunggulan kompetitif didekati dengan analisis rasio biaya privat (PCR). Dari hasil analisis menunjukkan bahwa daya saing produk nenas kaleng Indonesia dinilai cukup tinggi dan stabil baik dari segi finansial maupun ekonomi yang ditunjukkan nilai KBSD dan PCR kurang dari satu.

Gaya hidup, preferensi konsumen dan perilaku konsumtif masyarakat terhadap produk impor harus dikurangi. Sebaliknya mengkampanyekan kembali rasa cinta Indonesia dengan memperbanyak konsumsi produk dalam negeri agar produk dalam negeri dapat menjadi raja dinegerinya sendiri.

Dalam era perdagangan bebas ada dua alternatif yang dapat ditempuh untuk memenuhi kebutuhan daging ayam yaitu dengan memproduksi sendiri dengan mengembangkan usaha ternak ayam atau'dengan membeli dari luar negeri (impor). Jika kita punya keunggulan komparatif dalam mengusahakan ternak ayam secara teoritis kita lebih baik memproduksi sendiri dan sebaliknya.

Volume ekspor daging ayam mengalami peningkatan sebesar $30,64 \%$ pada tahun 2003 dibandingkan tahun sebelumnya, namun pada volume impornya terjadi sebaliknya (Anonimus, 2004). Tantangan yang dihadapi adalah untuk dapat bersaing di pasaran internasional maka produk-produk yang dihasilkan dituntut memiliki daya saing.

\section{Materi dan Metode}

Materi penelitian ini adalah peternak ayam ras pedaging di wilayah Kabupaten Sleman. Peternak yang diambil sebagai peternak responden dalam penelitian ini adalah sejumlah 30 orang peternak dengan rata-rata kepemilikan 6000 ekor.

Analisis keunggulan kompetitif menggunakan Private Cost Ratio (PCR). PCR merupakan rasio antara biaya faktor domestik dengan nilai tambah output dari biaya input yang 
diperdagangkan pada harga privat/secara finansial.

$$
\mathrm{PCR}=\frac{\text { Biaya input non tradeable }}{\text { Penerimaan }- \text { Biaya input tradeable }}
$$

Adapun kriteria yang diajukan adalah:

(1) bila PCR $>1$, maka usaha ternak komoditas ayam tidak efisien secara finansial, dan

(2) bila PCR $<1$, maka usaha ternak komoditas ayam efisien secara finansial.

Pengujian melalui analisis keunggulan komparatif dengan menggunakan Koefisien Biaya Sumberdaya Domestik(KBSD).

KBSD

$$
\frac{\text { biaya domestik(Rp) }}{\text { nilai output (US\$) - biaya asing (US\$) }}
$$

Kriteria yang diajukan adalah:

(1) jika KBSD $<1$ berarti aktivitas usaha ternak komoditas ayam telah efisien secara ekonomi dalam pemanfaatan sumberdaya domestik, sehingga pemenuhan permintaan domestik lebih menguntungkan dengan peningkatan produksi domestik, dan

(2) jika KBSD $>1$ berarti aktivitas usaha ternak komoditas ayam tidak efisien secara ekonomi dalam pemanfaatan sumberdaya domestik, sehingga pemenuhan permintaan domestik lebih menguntungkan dengan melakukan impor.

\section{Hasil dan Pembahasan}

\section{Analisis finansial dan analisis ekonomi}

Analisis keuntungan yang dibahas dalam penelitian ini mencakup dua aspek keuntungan, yaitu keuntungan finansial dan keuntungan ekonomi. Analisis keuntungan finansial merupakan analisis keuntungan yang diterima peternak berdasarkan harga yang berlaku di pasar pada tahun berjalan penelitian/harga privat. Analisis keuntungan ekonomi menggambarkan tingkat penerimaan bagi masyarakat keseluruhan pada perekonomian yang menunjukkan pasar persaingan sempurna dengan harga bayangan (Gittinger, 1986).
Nilai manfaat usaha ternak ayam dalam analisis ekonomi berbeda dengan besarnya nilai manfaat yang diperoleh dengan analisis finansial. Hal ini disebabkan karena output daging ayam yang diusahakan diperdagangkan di pasar dunia (traded goods) atau diekspor. Nilai-nilai ini diperoleh dengan jalan menyesuaikan harga-harga cif (cost, insurance and freight) atau fob (free on board) yang dikonversikan ke dalam nilai ekonomi dengan tarif-tarif yang relevan antara tempat usaha peternak atau batas proyek dengan suatu titik dimana harga cif atau fob ditentukan. Sama halnya dengan analisis finansial, dalam analisis ekonomi juga dilakukan alokasi biaya produksi ke dalam komponen domestik dan asing (Tabel 1).

Perbandingan antara hasil yang diperoleh pada analisis finansial dan ekonomi menunjukkan beberapa perbedaan yang sangat prinsip. Perbedaan terjadi pada nilai biaya dan penerimaan serta pada tingkat keuntungan yang diperoleh peternak, meskipun proporsinya menunjukkan urutan yang sejalan (Tabel 2). Keseluruhan perbedaan ditimbulkan oleh nilai ekonomi yang lebih tinggi, baik pada harga output maupun harga input yang dipergunakan pada analisis usaha ternak daging ayam.

\section{Analisis keunggulan kompetitif dan komparatif}

Analisis daya saing mengacu pada indikator keunggulan kompetitif dan komparatif bertujuan tercapainya pemakaian sumberdaya yang efisien. Pengukuran tingkat efisiensi finansial menggunakan indikator PCR sedangkan tingkat efisiensi ekonomi menggunakan indikator BSD, seperti yang dilakukan oleh beberapa peneliti (Suprihatini, 1998; Rusono, 1999; Ilham dan Dewa, 2001).

Keunggulan kompetitif yang diukur dengan menggunakan PCR merupakan rasio antara biaya faktor domestik dengan nilai tambah output dari biaya input yang diperdagangkan pada harga privat atau harga finansial. Nilai PCR diusahakan kurang dari satu karena untuk meningkatkan nilai tambah satu satuan diharapkan tambahan biaya faktor domestik lebih kecil dari satu. Nilai PCR dapat 
Tabel 1. Alokasi komponen biaya (\%) (Allocation of cost components (\%))

\begin{tabular}{|c|c|c|c|}
\hline Keterangan (Items) & $\begin{array}{c}\text { Komponen asing } \\
\text { (Tradeable component) }\end{array}$ & $\begin{array}{l}\text { Komponen domestik } \\
\text { (Domestic component) }\end{array}$ & Total \\
\hline $\mathrm{DOC}$ & 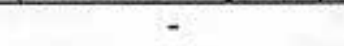 & 100 & 100 \\
\hline $\operatorname{Pakan}^{1}($ Feed $)$ & 50 & 50 & 100 \\
\hline Kandang $^{3}$ (Housing) & 50 & 50 & 100 \\
\hline Alat-alat ${ }^{3}$ (Tools of farm) & 50 & 50 & 100 \\
\hline Listrik $^{2}$ (Electricity) & 50 & 50 & 100 \\
\hline Tenaga kerja' (Labour) & - & 100 & 100 \\
\hline Lahan' (Land) & - & 100 & 100 \\
\hline Obat-obatan ${ }^{3}$ (Medicine) & 50 & 50 & 100 \\
\hline
\end{tabular}

Keterangan:(Note)

'Data primer (2004) (Primary data, 2004)

${ }^{2}$ Anonimus (1998)

${ }^{3}$ Sunandar (2001), Haryono (1991).

diperkecil dengan cara meminimumkan biaya faktor domestik atau memaksimumkan nilai tambah sehingga keuntungan dapat maksimum. Nilai PCR yang lebih kecil dari satu menunjukkan efisiensi finansial tercapai.

Analisis keunggulan komparatif usaha ternak ayam yang menghasilkan komoditas daging ayam diukur dengan menggunakan parameter KBSD merupakan perbandingan antara biaya faktor domestik dengan nilai tambah output dari biaya input yang diperdagangkan pada harga ekonomi. Suatu aktivitas ekonomi diharapkan memiliki KBSD $<1$ yang berarti tercapai efisiensi secara ekonomi, sedangkan bila nilai KBSD $>1$ menunjukkan semakin terjadi pemborosan sumberdaya domestik. Perhitungan biaya sumberdaya domestik diturunkan dari keuntungan ekonomi/sosial bersih yang didapatkan dari hasil usaha ternak ini.

Hasil perhitungan biaya faktor domestik dan nilai tambah output pada tingkat harga privat/secara financial dan ekonomi pada penelitian ini menghasilkan angka 0,06837 dan 0,12767 . Angka ini menunjukkan bahwa mengusahakan daging ayam di dalam negeri memiliki efisiensi secara finansial (keunggulan kompetitif) dan secara ekonomi (keunggulan komparatif). Dengan kata lain untuk meningkatkan nilai tambah output sebesar satu satuan diperlukan tambahan biaya faktor domestik sebesar 0,06837 dan 0,12767 satuan.

Keterkaitannya dengan nilai tukar mata uang asing, nilai KBSD 0,12767 ini menunjukkan bahwa untuk" setiap satu dolar devisa negara yang dikeluarkan untuk mengimpor daging ayam, jika digunakan untuk memproduksi di dalam negeri hanya dibutuhkan biaya sebesar 0,12767 dolar. Dengan kata lain mengusahakan daging ayam dapat menghemat devisa lebih dari 87 persen dari biaya impor yang harus dikeluarkan.

Melihat dari fluktuasi nilai tukar rupiah terhadap dolar jika dikaitkan dengan peningkatan daya saing ternyata lebih disebabkan oleh menurunnya nilai tukar rupiah terhadap dolar Amerika. Dengan melemahnya nilai rupiah terhadap dolar AS maka harga produk impor secara relatif akan meningkat. Kondisi ini menyebabkan penerimaan sosial secara relatif meningkat, sehingga koefisien BSD menjadi semakin kecil. Hal ini juga didukung oleh besarnya input yang digunakan dalam usaha ini menggunakan sumberdaya domestik yaitu dengan perbandingan $70 \%$ domestik dan $30 \%$ asing. 
Tabel 2. Analisis finansial usaha ternak ayam di Kabupaten Sleman tahun 2004.

(Financial analysis of chicken farming in Sleman Regency, 2004)

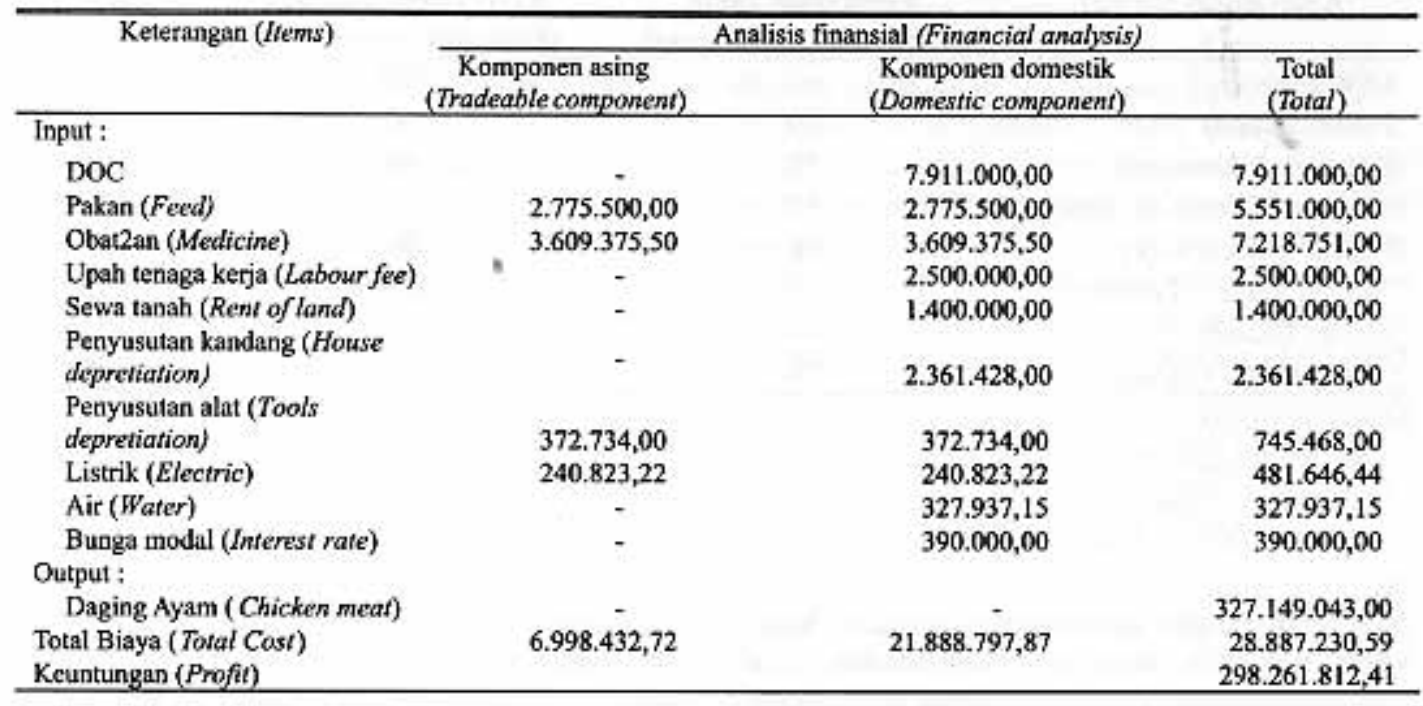

Tabel 3. Analisis ekonomi usaha ternak ayam di Kabupaten Sleman tahun 2004. (Economic analysis of chicken farming in Sleman Regency, 2004)

\begin{tabular}{|c|c|c|c|}
\hline \multirow[t]{2}{*}{ Keterangan (Items) } & \multicolumn{3}{|c|}{ Analisis ckonomi (Economic analysis) } \\
\hline & $\begin{array}{c}\text { Komponen asing } \\
\text { (Tradeable component) }\end{array}$ & $\begin{array}{l}\text { Komponen domestik } \\
\text { (Domestic component') }\end{array}$ & $\begin{array}{l}\text { Total } \\
\text { (Total) }\end{array}$ \\
\hline \multicolumn{4}{|l|}{ Input : } \\
\hline DOC & & $4.617 .368 .382,73$ & $4.617 .368 .382,73$ \\
\hline Pakan (Feed) & $2.775 .500,00$ & $2.775 .500,00$ & $5.551 .000,00$ \\
\hline Obatzan (Medicine) & $82.874,48$ & $82.874,48$ & $165.748,97$ \\
\hline Upah tenaga kerja (Labour & & & \\
\hline fee) & - & $2.300 .000,00$ & $2.300 .000,00$ \\
\hline Sewa tanah (Rent of land) & - & $1.400 .000,00$ & $1.400 .000,00$ \\
\hline $\begin{array}{l}\text { Penyusutan kandang (House } \\
\text { depreciation) }\end{array}$ & - & $2.361,428,00$ & $2.361 .428,00$ \\
\hline \multicolumn{4}{|l|}{ Penyusutan alat (Tools } \\
\hline depreciation) & $372.734,00$ & $372.734,00$ & $745,468,00$ \\
\hline Listrik (Electric) & $240,823,22$ & $240.823,22$ & $481.646,44$ \\
\hline Air (Water) & - & $327.937,15$ & $327.937,15$ \\
\hline Bunga modal (Interest rate) & - & $390.000,00$ & $390.000,00$ \\
\hline \multicolumn{4}{|l|}{ Output: } \\
\hline Daging ayam (Chicken meat) & - & - & $36.249 .941 .883,87$ \\
\hline Total biaya ( Total cost ) & $3.471 .931,70$ & $4.627 .619 .679,58$ & $4.631 .091 .611,28$ \\
\hline Keuntungan (Profit) & & & $31.618 .850 .272,59$ \\
\hline
\end{tabular}




\section{Kesimpulan}

Usaha daging ayam yang diusahakan peternak merupakan usaha yang dapat menghasilkan komoditas daging ayam yang memiliki harga lebih murah dan kualitas sama dengan daging ayam impor serta mampu bersaing di pasar internasional.

Kemampuan bersaing komoditas daging ayam ini ditunjukkan dengan kemampuan memanfaatkan sumberdaya lokalnya sehingga biaya faktor produksinya dapat seminimal mungkin dan mampu mempertahankan usaha ternaknya yang menghasilkan keuntungan baik secara finansial maupun ekonomi.

\section{Daftar Pustaka}

Anonimus, 1998. Tabel input output Indonesia. - 1995. Badan Pusat Statistik. Jakarta.

Anonimus. 2004. Buku Statistik Peternakan Tahun 2003. Dirjen Bina Produksi Peternakan Deptan RI. Jakarta.

Gittinger, J. P. 1986. Analisis Ekonomi Proyekproyek Pertanian. Edisi Kedua, Terjemahan. Universitas Indonesia Press. Jakarta.

Haryono, D. 1991. Keunggulan Komparatif dan Dampak Kebijaksanaan pada Produksi
Kedelai. Jagung dan Ubi Kayu di Propinsi Lampung. Tesis Program Pascasarjana IPB. Bogor

Ilham, N. dan K. S. Dewa. 2001. Analisis Daya Saing Susu Segar dalam Negeri Pasca Krisis Ekonomi dan Dampak Kebijakan Pemerintah terhadap Usaha Peternakan Sapi Perah di Indonesia. JAE Volume 19 No1. Pusat Penelitian Agroekonomi Badan Litbang Pertanian. Jakarta.

Rusono, N. 1999. Analisis Daya Saing Beberapa Komoditi Tanaman Pangan pada Beberapa Lokasi Pegembangan : Sebagai Bahan Pertimbangan dalam Memilih Komoditi Unggulan dan wilayah Andalan Bagi Pengembangan-nya. Tesis. Program Pascasarjana IPB. Bogor.

Sunandar, N. 2001. Dampak Kebijakan Nasional Impor Susu dan Keunggulan Komparatif Usaha Temak Sapi Perah di Jawa Barat, Tesis S-2, Program Pascasarjana UGM.Yogyakarta.

Suprihanti, A. 1998. Analisis Daya Saing Teh Hitam Indonesia di Pasar Internasional. Tesis Program Pascasarjana IPB. Bogor.

Suprihatini, R. 1998. Analisis Daya Saing Nenas Kaleng Indonesia. JAE Volume 17. Pusat Penelitian Agroekonomí Badan Litbang Pertanian. Jakarta. 